\title{
Size Selective Feeding in Cyclidium glaucoma (Ciliophora, Scuticociliatida) and Its Effects on Bacterial Community Structure: A Study from a Continuous Cultivation System
}

\author{
T. Posch, ${ }^{1}$ J. Jezbera, ${ }^{2}$ J. Vrba, ${ }^{2}$ K. Šimek ${ }^{2,3}$ J. Pernthaler, ${ }^{4}$ S. Andreatta, ${ }^{1}$ B. Sonntag ${ }^{1}$ \\ ${ }^{1}$ Institute for Zoology and Limnology, University of Innsbruck, A-6020 Innsbruck, Austria \\ ${ }^{2}$ Hydrobiological Institute of the Czech Academy of Sciences, CZ-370 05 Ceské Budejovice, \\ The Czech Republic \\ ${ }^{3}$ Faculty of Biological Sciences, University of South Bohemia, CZ-370 05 Ceské, Budejovice, \\ The Czech Republic \\ ${ }^{4}$ Max-Planck-Institute for Marine Microbiology, D-28359 Bremen, Germany
}

Received: 25 July 2000; Accepted: 28 November 2000; Online Publication: 8 August 2001

A B S S T R A A T

Three aspects of size selective feeding by the scuticociliate Cyclidium glaucoma were studied in continuous cultivation systems. Firstly, grazing-induced changes in abundance, biomass, and size structure of a bacterial community were investigated. Secondly, we studied possible grazingprotection mechanisms of bacteria as a response to permanent presence of the predator. And finally, we were looking for potential feedback mechanisms within this predator-prey relationship, i.e., how the ciliate population reacted to a changed, more grazing-protected bacterial community. The first stage of the cultivation system consisted of the alga Cryptomonas sp. and the accompanying mixed bacterial community. These organisms were transferred to two second stage vessels, a control stage without ciliates and a second one inoculated with C. glaucoma. After the first week, the abundance of bacteria in the latter decreased by $60 \%$ and remained stable until the end of the experiment $(65$ d), whereas bacterial biomass was less affected (393 $\mu \mathrm{g} \mathrm{C} \mathrm{L} \mathrm{L}^{-1}$ during days $0-7,281 \mu \mathrm{g} \mathrm{C} \mathrm{L} \mathrm{L}^{-1}$ afterwards). The mean bacterial cell volume doubled from $0.089 \mu \mathrm{m}^{3}$ to $0.167 \mu \mathrm{m}^{3}$, which was mainly due to increasing cell widths. During the whole investigation period formation of colonies or filaments was not observed, but we found a clear feedback of ciliates on bacterial size. An increase in bacterial cell volume was always followed by a decline of the predator population, resulting in a yet undescribed type of microbial predator-prey relation. Literature and our own data on the optimal food size range grazed by C. glaucoma showed that bacterial cell width rather than length was responsible for that observed phenomenon. Finally, we suggest that uptake rates of spherical latex beads give only limited information on truly ingestible prey volumes and that prey geometry should be considered in future studies on size selective feeding of protists. 


\section{Introduction}

Feeding on bacteria by flagellates and ciliates perhaps represents the oldest predator-prey interaction we can study in nature. Because of the long evolution of this microbial relationship an enormous degree of adaptations on both sides, bacteria and protists, should be expected [15]. When studying the principles of this interaction, three theoretical aspects need to be considered:

1. Protistan feeding can directly influence the size structure, community composition, and productivity of a bacterial community $[12,23,37,38]$. These changes are caused by selective grazing of protists on specific bacteria, which consequently has an impact on the whole bacterial community (BC). Several characteristics of the bacterial cell, such as motility, cell surface properties, size, and activity state (growth or division), can be criteria for a protistan predator to prefer or avoid it as food [17, 32, 41]. Until now, most studies in this field focused on the size selective feeding of ciliates and flagellates and its various effects on bacteria. Not only does the uptake of distinct prey size classes change the size distribution of a BC [23, 40], but feeding on larger, i.e., more active or dividing, cells affects the productivity of the whole community [2, $3,32]$. On the one hand, grazing controls the bacterial production rather than the standing stock. On the other hand, size selective feeding can change the $\mathrm{BC}$ composition if the mean cell sizes of some particular populations lie in the optimal food size range of the predator [20,36]. As a consequence, grazing could modify the interspecific competition within a BC. This phenomenon has been observed for an experimental system composed of two strains [11].

2. Bacteria developed several grazing-defence strategies in order to decrease vulnerability or to avoid grazing induced mortality. Some bacterial strains show a high phenotypic plasticity and can outgrow the optimal food size range of the predator $[13,34,36]$. Another strategy depends on an increase of growth rate to compensate for cell losses [20, 23]. One can also speculate about a decrease in growth rate and consequently cell size, to minimize the grazing induced cell losses, that, to our knowledge, has not been described yet. Finally, the formation of inedible colonies yields another efficient strategy against being grazed $[8,14]$.

3. All the above-mentioned aspects can result in a new situation, where flagellates and ciliates must adapt to more grazing-protected BCs. In theory, this reaction can start a cyclic relationship, whereby predators affect the main characteristics of a prey and vice versa (Chapter 10 in [1]). In nature, it is very difficult to observe this phenomenon for microbial predator-prey interactions. Tanaka et al. [39] documented such a predator-prey cycle, when they related seasonal values of bacterial and flagellate abundance. However, this relationship is complex, as not only do protistan predators reduce bacterial biomass, but feeding also results in a remineralization of nutrients whereby protists themselves support their bacterial prey [38].

Studying the effects of size selective feeding in the field is always hampered by the fact that bottom-up and topdown factors are simultaneously operating in bacterial communities [24]. To analyze protistan grazing and its effects on $\mathrm{BCs}$, natural conditions have been manipulated by the use of dialysis bags, the addition of fluorescently labeled bacteria (FLB), or size fractionations [2, 31, 32, 37]. To investigate size selective feeding in detail, experiments with batch cultures or chemostats are particularly helpful $[9,26]$. In particular, continuous cultivation systems are useful because chemical and physical parameters are controlled, thus allowing specific manipulations and detailed observations of predator-prey interactions.

Here, we present a study on the feeding behavior of $C y$ clidium glaucoma and how this predator affected a mixed $\mathrm{BC}$, which was growing in association with Cryptomonas sp. strain 26.80 (formerly Rhodomonas sp.). This algae-bacteria community has already been used in many studies on the feeding behavior of protists $[20,23,26-29,36]$. The scuticociliate was chosen for our experiments because several authors have already studied the size selectivity of the genus Cyclidium [5, 19, 23, 30, 35]. Additionally, this species seems to be cosmopolitan, occurring in freshwater habitats of different trophic state (see references in [6, 7]). In experiments with continuous cultivation systems we addressed the three aspects of microbial predator-prey interactions described above. Our hypotheses were, first, that grazing by C. glaucoma will change bacterial cell size, abundance, and biomass; second, that bacteria may express grazing defence mechanisms under continuous grazing pressure; and finally, that grazing-induced changes of the BC may cause a strong feedback on the survival of the predator population.

\section{Materials and Methods}

\section{Cultures and Continuous Cultivation System}

A two stage continuous cultivation system was used in our experiments (Fig. 1, [23]). The first stage (I-stage) was inoculated with the cryptomonad Cryptomonas sp. formerly Rhodomonas sp. (strain 


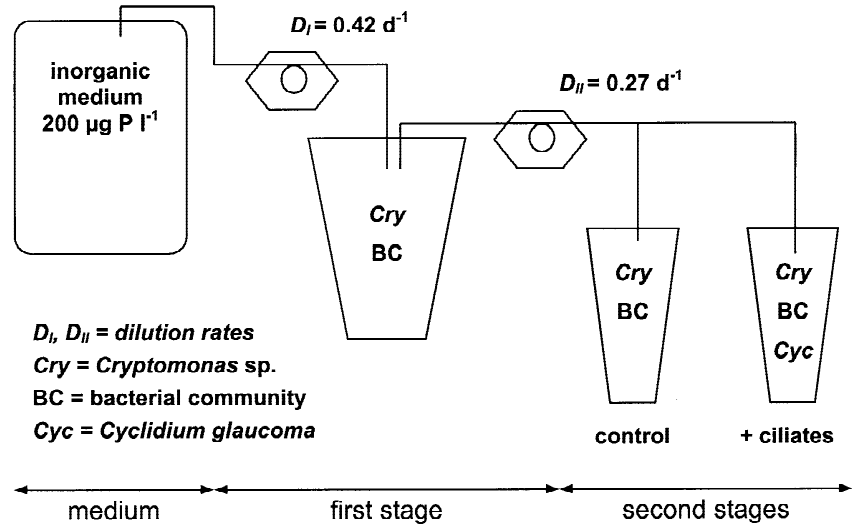

Fig. 1. Simplified scheme of the two-stage continuous cultivation system.

26.80, algal culture collection, Göttingen, Germany) and its associated BC growing at a dilution rate of $0.42 \mathrm{~d}^{-1}$ (Fig. 1). The algae were cultured on inorganic medium WC [10] with a phosphorus content of $200 \mu \mathrm{g} \mathrm{L}^{-1}$ at $18^{\circ} \mathrm{C}$ and continuous light $\left(118 \mu \mathrm{E} \mathrm{m} \mathrm{m}^{-2}\right.$ $\mathrm{s}^{-1}$ ). The algae-bacteria association appears to be obligatory as algae die without accompanying bacteria (Weisse T, pers. com.). The mixed BC itself depends on the extracellular organic carbon (EOC) released by Cryptomonas sp. and cannot grow on the inorganic medium itself (unpublished data). At least eight different bacterial taxa are associated with the algae, of which four seem to be dominant as determined by fluorescence in situ hybridization [21]. The algal-bacterial community of I-stage was pumped continuously via peristaltic pumps into second stage vessels at a dilution rate of $0.27 \mathrm{~d}^{-1}$ (Fig. 1). One vessel served as control without ciliates (II-control); the second one was inoculated with Cyclidium glaucoma (II-ciliate). The day of the predator's inoculation was set as day 0 . The system was run at quasi steady state conditions 5 days prior to the inoculation with ciliates, and then maintained for 65 days. Ciliates were originally cultured in wheat seed cultures under the same experimental conditions and separated from their associated bacteria by repeated filtration and washing with inorganic medium WC before inoculation [36]. C. glaucoma was originally isolated from Rímov Reservoir (CZ) by M. Macek.

\section{Determination of Abundance and Cell Volume}

Starting on day 0 , samples were taken every day for 2 weeks and weekly afterwards. Subsamples were fixed with Lugol's solution $(0.5 \%$ final concentration $=$ f.c. $)$, followed immediately by formaldehyde (3\% f.c.) and decolorized with several drops of sodium thiosulfate [33]. Cells were stained with the fluorescent dye DAPI ( $2 \mu \mathrm{g} \mathrm{ml} \mathrm{m}^{-1}$ f.c.). We used black polycarbonate filters (Osmonics) with a pore size of $0.22 \mu \mathrm{m}$ and $1.0 \mu \mathrm{m}$ for counting and sizing bacteria and protists, respectively. Between 500 and 700 bacteria and at least 100 protists were counted for each sample. Images of DAPI-stained bacteria were recorded with a highly sensitive CCD camera (Optronics ZVS-47EC), mounted on a Zeiss Axiophot microscope, and processed with the image analysis software LUCIA D (http://www.lim.cz). Areas and perimeters of 500 to 700 bacteria were measured per sample and cell dimensions (length, width, volume) calculated according to the algorithms published by Massana et al. [16]. For bacterial cell carbon content and total bacterial biomass the following formulas were applied [18]:

$$
\begin{aligned}
\mathrm{C}_{\mathrm{B}} & =120 \times \mathrm{MCV}_{\mathrm{B}}{ }^{0.72} \\
\mathrm{BM}_{\mathrm{B}} & =\mathrm{C}_{\mathrm{B}} \times \mathrm{N}_{\mathrm{B}}
\end{aligned}
$$

where $C_{B}$ is bacterial cell carbon (fg C cell ${ }^{-1}$ ), $\mathrm{MCV}_{\mathrm{B}}$ mean bacterial cell volume $\left(\mu \mathrm{m}^{3}\right), \mathrm{BM}_{\mathrm{B}}$ is bacterial biomass $\left(\mu \mathrm{g} \mathrm{C} \mathrm{L}{ }^{-1}\right)$, and $\mathrm{N}_{\mathrm{B}}$ stands for bacterial abundance (cells $\mathrm{L}^{-1}$ ). For each sample, cell dimensions of 50-100 protists were measured using the image analysis software described above. Ciliate cell volumes were calculated using the equation for ellipsoids and converted to carbon content according to the formula of Putt and Stoecker [25]:

$$
\mathrm{C}_{\mathrm{C}}=0.14 \times \mathrm{MCV}_{\mathrm{C}}
$$

where $\mathrm{C}_{\mathrm{C}}$ is ciliate carbon content $\left(\mathrm{pg} \mathrm{C}\right.$ cell ${ }^{-1}$ ) and $\mathrm{MCV}_{\mathrm{C}}$ mean ciliate cell volume $\left(\mu \mathrm{m}^{3}\right)$. Total ciliate biomass $\left(\mathrm{BM}_{\mathrm{c}}\right)$ was calculated using formula $(2)$. Growth rates of ciliates $\left(\mu_{C}\right)$ were determined with the following formula:

$$
\mu_{\mathrm{C}}=\left(\ln \left(\mathrm{N}_{\mathrm{C} \mathrm{t} 1} / \mathrm{N}_{\mathrm{C} \mathrm{t} 0}\right) /(\mathrm{t} 1-\mathrm{t} 0)\right)+\mathrm{D}_{\mathrm{II}}
$$

where $\mathrm{N}_{\mathrm{C} \text { to }}$ and $\mathrm{N}_{\mathrm{C} \text { t1 }}$ are the numbers of ciliates (cells $\mathrm{L}^{-1}$ ) on two consecutive sampling dates, $\mathrm{t} 0$ and $\mathrm{t} 1(\mathrm{~d})$, and $\mathrm{D}_{\mathrm{II}}\left(\mathrm{d}^{-1}\right)$ stands for the dilution rate of the second stages. For more details on sampling, sample processing, image analysis procedures, and microscopy, see $[22,23]$.

\section{Determination of Feeding Rates}

Feeding rates of ciliates were determined via uptake rates of fluorescently labeled bacteria (FLB, $[31,36]$ ) during days 1 to 16 . Bacteria of the first stage were used for the preparation of FLBs. Prey surrogates were added to live subsamples at concentrations between 10 and $15 \%$ of the bacterial abundance. Hourly uptake rates were calculated from 5 to $10 \mathrm{~min}$ feeding periods. The mean cell size of FLBs were $0.94 \times 0.58 \mu \mathrm{m}$ resulting in a mean cell volume of $0.224 \mu^{3}$. Total grazing rates (TGR) were calculated as ciliate abundance times hourly uptake rates.

\section{Determination of Algal and Bacterial Production}

Bacterial and algal production in I-stage and the second stages were calculated by the following formulas:

$$
\begin{aligned}
P_{I}=N_{I} \times D_{I} & \text { valid for I-stage } \\
P_{I I}=\left(N_{I I} \times D_{I I}\right)-\left(N_{I} \times D_{I I}\right) & \text { valid for II-control } \\
P_{I I}=\left(N_{I I} \times D_{I I}\right)-\left(N_{I} \times D_{I I}\right)+T G R & \text { valid for II-ciliate }
\end{aligned}
$$

where $\mathrm{P}$ (cells $\mathrm{ml}^{-1} \mathrm{~d}^{-1}$ ) stands for algal or bacterial production rates, $\mathrm{N}$ (cells $\mathrm{ml}^{-1}$ ) for algal or bacterial abundance, and $\mathrm{D}\left(\mathrm{d}^{-1}\right)$ for the dilution rates, the indices ${ }_{\mathrm{I}}$ and ${ }_{\mathrm{II}}$ characterize values of the first and second stages, respectively; and TGR (cells $\mathrm{ml}^{-1} \mathrm{~d}^{-1}$ ) is the total grazing rate.

\section{Determination of Bacterial Community Composition}

The taxonomic composition of bacterial communities in all stages was observed by FISH (fluorescent in situ hybridization) using CY3-labeled oligonucleotide probes specifically designed to target 
bacterial phylotypes associated with Cryptomonas sp. [21]. This data set was only determined for the period of daily sampling until day 16. We chose three oligonucleotide probes, which allowed the detection of quantitatively important members of the microbial community. Two probes, ALF1-645 and BET3-447, targeted specific phylotypes within the alpha- and beta-Proteobacteria, respectively, whereas the probe CF2-853 targeted a lineage within the Cytophaga-Flavobacterium cluster. Using FISH and considering the dilution rates, we could calculate the ratio between the daily input of each taxonomic unit (cells $\mathrm{ml}^{-1} \mathrm{~d}^{-1}$ ) and the actual standing stock of this unit in the corresponding second stage (cells $\mathrm{ml}^{-1}$ ). Details of probe sequences, their targets, and hybridization conditions are described elsewhere [21].

\section{Results}

\section{Grazing-Induced Changes in Bacterial Abundance and Cell Dimensions}

In the I-stage, algal and bacterial abundance was very stable during the whole experiment (Fig. 2, Table 1). The mean cell number of Cryptomonas sp. was $1.7 \pm 0.3 \times 10^{5}$ cells ml $^{-1}$ (mean \pm one S.D.), while that of bacteria was $2.4 \pm 0.3 \times 10^{7}$ cells $\mathrm{ml}^{-1}$. In II-control, the abundances of both algae $(2.4 \pm$ $0.5 \times 10^{5}$ cells $\left.\mathrm{ml}^{-1}\right)$ and bacteria $\left(3.3 \pm 0.7 \times 10^{7}\right.$ cells $\left.\mathrm{ml}^{-1}\right)$ were higher than in the I-stage. Averages of bacterial and algal production rates in the I-stage were $1.3 \pm 0.1 \times 10^{7}$ cells $\mathrm{ml}^{-1} \mathrm{~d}^{-1}$ and $8.9 \pm 1.4 \times 10^{4}$ cells $\mathrm{ml}^{-1} \mathrm{~d}^{-1}$ for the whole experiment (see Fig. 2, lower panels). In II-control, both bacterial $\left(0.2 \pm 0.2 \times 10^{7}\right.$ cells $\left.\mathrm{ml}^{-1} \mathrm{~d}^{-1}\right)$ and algal $(1.6 \pm 1.1$ $\times 10^{4}$ cells $\left.\mathrm{ml}^{-1} \mathrm{~d}^{-1}\right)$ production rates were markedly lower. However, bacteria showed still positive production rates whereby their cell numbers were increasing during days 10 to 20 (Fig. 2).

In II-ciliate, a mean algal abundance of $2.5 \pm 0.5 \times 10^{5}$ cells $\mathrm{ml}^{-1}$ was determined. C. glaucoma was exponentially growing until the day 7 and reached the maximum abundance of 4,400 cells $\mathrm{ml}^{-1}$ on day 11 (Fig. 2). During this period a growth rate of $0.83 \mathrm{~d}^{-1}$ was determined. In the last phase of the experiment ciliate growth rate $\left(0.26 \mathrm{~d}^{-1}\right)$ was the same as the dilution rate of the second stages $\left(0.27 \mathrm{~d}^{-1}\right.$, Table 1). With increasing numbers of ciliates, bacterial abundance dropped to ca. $30 \%$ of the initial value and remained $<10^{7} \mathrm{ml}^{-1}$ until the day 65 . Throughout the experiment, the abundances of ciliates and bacteria were significantly negatively correlated $(R=-0.50, p<0.05, n=23$, Spearman rank correlation). Total grazing rates were greater than $10^{6}$ bacteria $\mathrm{ml}^{-1} \mathrm{hr}^{-1}$ during the first 14 days (Table $1)$. In comparison to II-control we observed a slightly increased algal production $\left(2.2 \pm 0.9 \times 10^{4}\right.$ cells $\left.\mathrm{ml}^{-1} \mathrm{~d}^{-1}\right)$ and
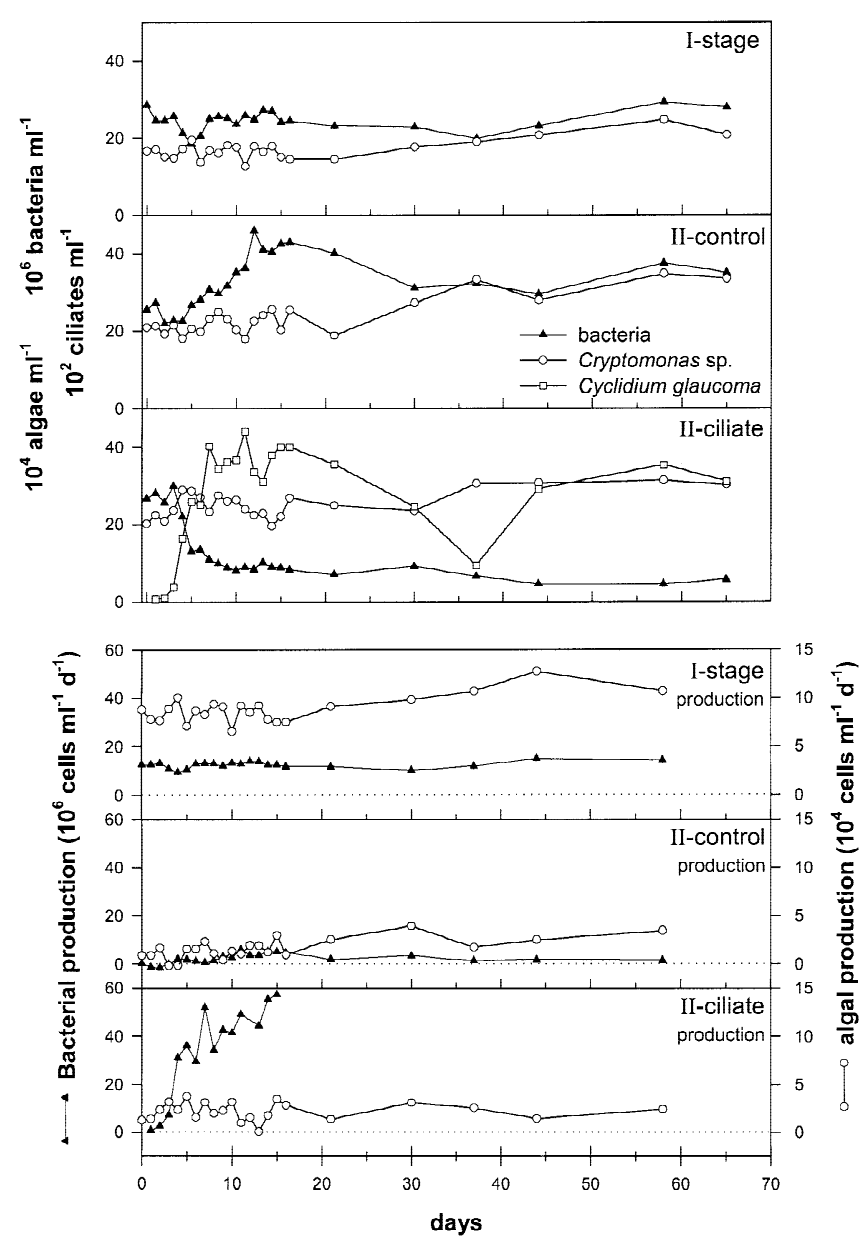

Fig. 2. Abundance of Cryptomonas sp., heterotrophic bacteria, and Cyclidium glaucoma in the first and second stages of the continuous cultivation system during 65 days (three upper panels). Cell production per day of Cryptomonas sp. and heterotrophic bacteria (three lower panels): Grazing rates of ciliates were only determined until day 16; therefore, no calculation of bacterial production was possible in that stage for the rest of the experiment. Dashed lines indicate the zero-lines of algal and bacterial production.

a steep increase of bacterial production $\left(3.5 \pm 1.9 \times 10^{7}\right.$ cells $\mathrm{ml}^{-1} \mathrm{~d}^{-1}$ ) during days 0-16 (Fig. 2, lower panels). Grazing rates of C. glaucoma (Table 1) were only determined during 16 days; therefore, bacterial production rates could not be calculated for the following investigation period. After the day 8 , bacterial abundance in II-ciliates remained very stable with an average of $0.8 \pm 0.2 \times 10^{7}$ cells $\mathrm{ml}^{-1}$. This value is equivalent to the calculated inflow of bacteria $(0.8 \pm 0.1$ cells $\mathrm{ml}^{-1} \mathrm{~d}^{-1}$ ) from the I-stage into II-ciliates.

Mean bacterial cell volumes $\left(\mathrm{MCV}_{\mathrm{B}}\right)$ of I-stage and IIcontrol were quite stable throughout 2 months $(0.074 \pm$ $0.014 \mu^{3}$ and $0.087 \pm 0.016 \mu \mathrm{m}^{3}$ ) and were not significantly different during the three periods of the experiment (Table 
Table 1. Changes in bacterial community structure due to grazing activity of Cyclidium glaucoma in a two-stage continuous cultivation system (dilution rates: I-stage $=0.42 \mathrm{~d}^{-1}$, II-stages $\left.=0.27 \mathrm{~d}^{-1}\right)^{\mathrm{a}}$

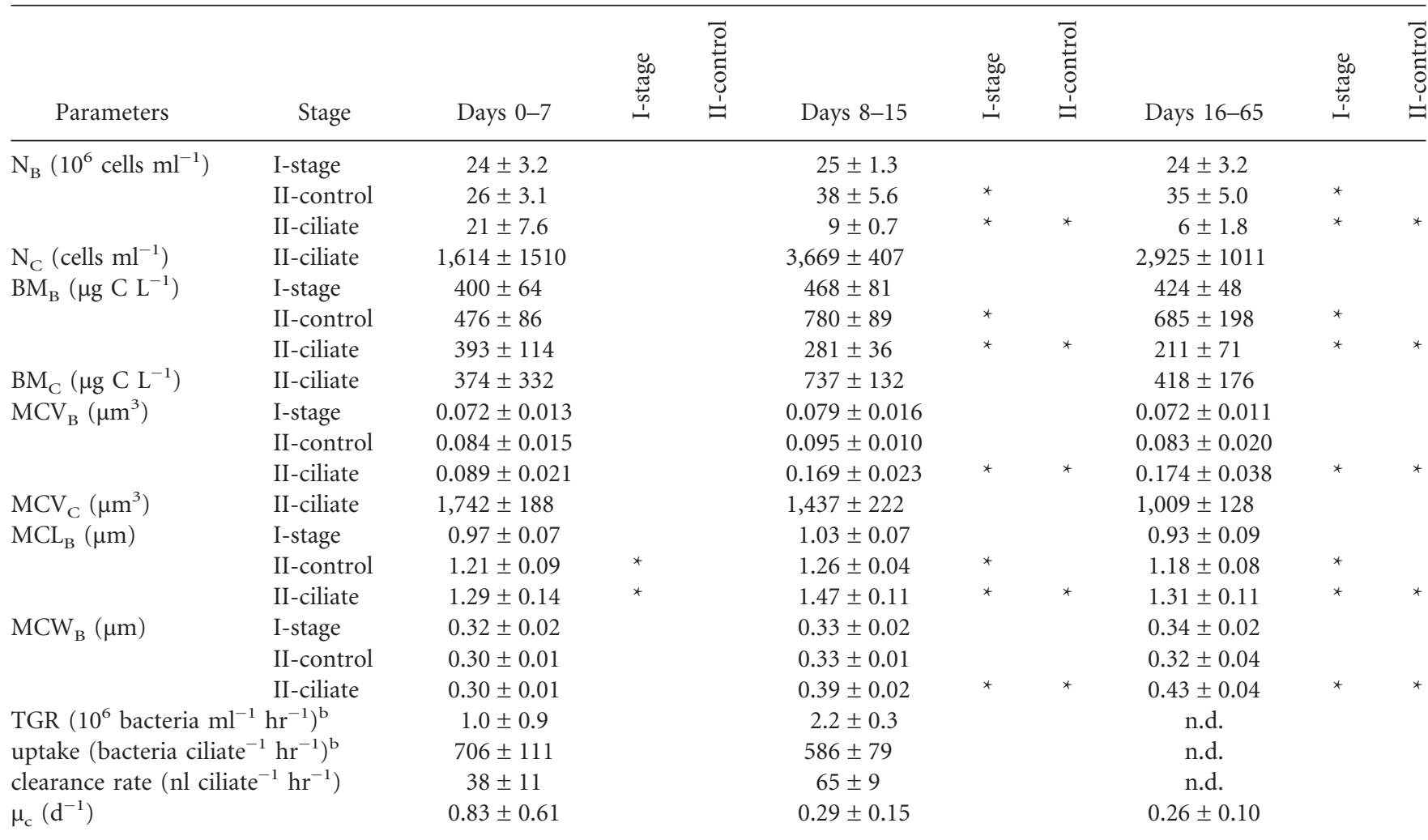

${ }^{a}$ Days 0-7: exponential growth of ciliates, daily sampling, $n=8$. Days 8-15: ciliate numbers stabilized, daily sampling, $n=8$. Days $16-65$ : ca. weekly sampling, $n=7$. Abbreviations: Abundance of bacteria $\left(\mathrm{N}_{\mathrm{B}}\right)$ and ciliates $\left(\mathrm{N}_{\mathrm{C}}\right)$, biomass of bacteria $\left(\mathrm{BM}_{\mathrm{B}}\right)$ and ciliates $\left(\mathrm{BM}_{\mathrm{C}}\right)$, mean cell volume of bacteria $\left(\mathrm{MCV}_{\mathrm{B}}\right)$ and ciliates $\left(\mathrm{MCV}_{\mathrm{C}}\right)$, mean bacterial cell length and width $\left(\mathrm{MCL}_{\mathrm{B}}, \mathrm{MCW}_{\mathrm{B}}\right)$, total grazing rate (TGR), growth rate of ciliates $\left(\mu_{\mathrm{C}}\right)$, first stage $(\mathrm{I}$-stage), second stages without (II-control) and with ciliates (II-ciliate). Significant differences between stages are marked with an asterisk (two way ANOVA, Tukey test).

${ }^{\mathrm{b}}$ Determined via the FLB technique

1). In contrast, bacteria in II-ciliate increased their $\mathrm{MCV}_{\mathrm{B}}$ up to a maximum value of $0.246 \mu \mathrm{m}^{3}$. During the first week, bacteria had an average $\mathrm{MCV}_{\mathrm{B}}$ of $0.089 \mu \mathrm{m}^{3}$ and an average of $0.171 \mu \mathrm{m}^{3}$ from day 8 until the end of the study. About $80 \%$ of bacteria in II-control as well as in II-ciliate were between 0.5 and $2.5 \mu \mathrm{m}$ long (Fig. 3). Between days 7 and 37, the proportion of cells with lengths $<1 \mu \mathrm{m}$ slightly decreased in II-ciliate. In contrast, bacterial cell widths increased in II-ciliate. Initially $80 \%$ of bacteria had a cell width between 0.2 and $0.4 \mu \mathrm{m}$, whereas after day 10 , most bacteria were between 0.3 and $0.7 \mu \mathrm{m}$ wide (Fig. 3). In II-ciliate, the proportion of cells $>0.15 \mu \mathrm{m}^{3}$ strongly increased after the first week (Fig. 3). This volume corresponds to a sphere with an equivalent diameter of ca. $0.65 \mu \mathrm{m}$. Differences between cell dimensions in II-control and II-ciliate were tested for each day by planned comparison (multivariate ANOVA, Fig. 3). After the first week, bacterial width and volume in II-ciliate were significantly different $(p<0.001)$ from dimensions in II-control (Fig. 3). In contrast, we found no differences be- tween bacterial length in the two second stages during the last period of the experiment.

\section{Grazing Induced Changes of Bacterial Community Composition}

Bacteria in II-control, targeted with the probes BET3-447 and CF2-853, showed low growth as their ratios of input to standing stock were slightly smaller than the expected value based on the dilution rate of $0.27 \mathrm{~d}^{-1}$ (Fig. 4). The ratio of input to standing stock of bacteria targeted with ALF1-645 was very low indicating that these bacteria were well growing in II-control and increased their percentage on the total bacterial community (see also [21]). Bacteria in II-ciliate detected via BET3-447 and CF2-853 probes seemed to be strongly grazed by C. glaucoma as their daily input was up to four times higher in comparison to the standing stock (Fig. 4). Only bacteria hybridizing with the probe ALF1-645 were less affected by grazing (see also [21]). 


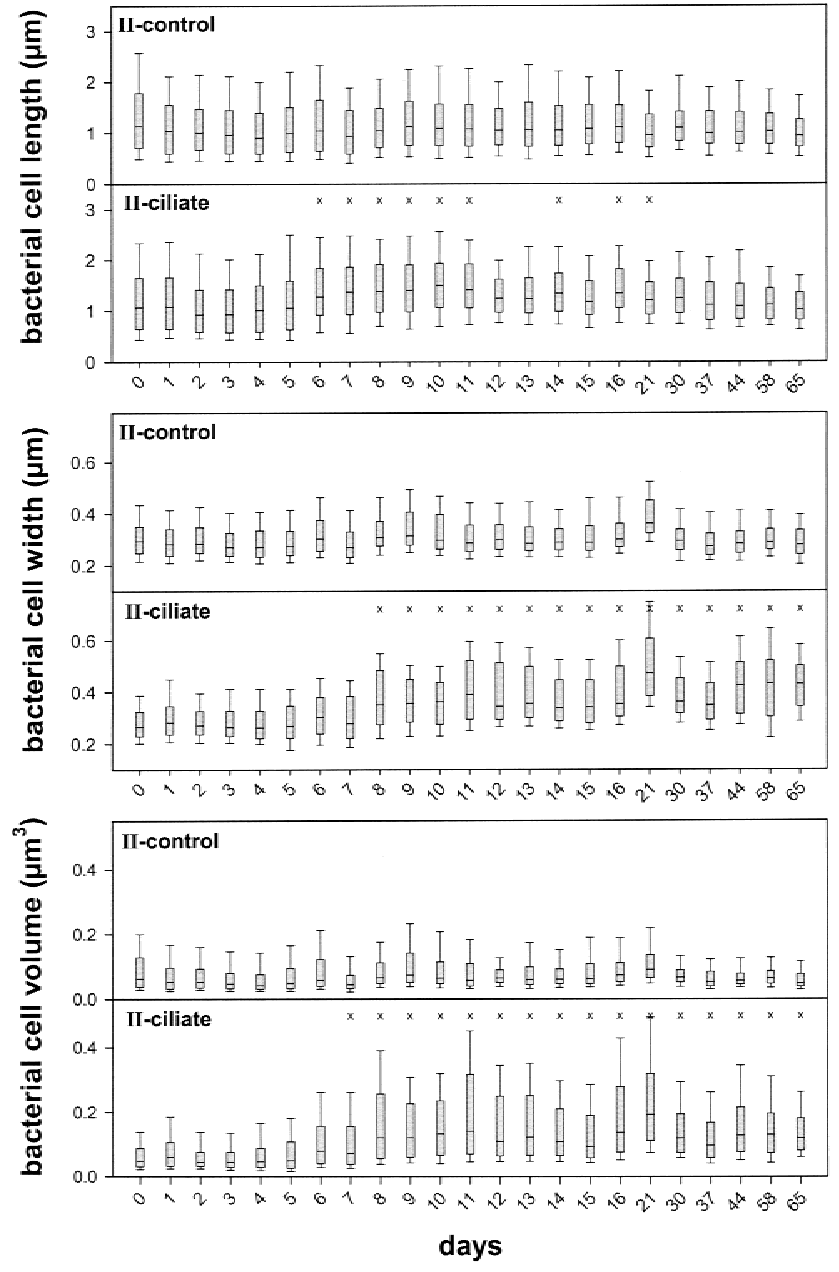

Fig. 3. Box and whisker plots of bacterial cell dimensions in IIcontrol and under grazing pressure by Cyclidium glaucoma (IIciliate). Every bar is based on the measurement of 500-700 bacteria. The bars show the 25th, 50th, and 75th percentiles of all data and whiskers stand for the 10th and 90th percentiles. The days where cell dimensions in II-ciliate and II-control were significantly different $(p<0.001)$ are marked $(\mathrm{x})$.

\section{Cyclic Relationship between Predator and Prey Size}

Although bacterial abundance in II-ciliate remained quite stable after day 10, numbers of C. glaucoma were fluctuating and showed a minimum on day 37 (Fig. 2). Assuming that bacterial cell size has a strong impact on the feeding efficiency of the bacterivorous predator, we followed the total ciliate biomass in relation to bacterial cell volume (Fig. 5). The following predator-prey cycle was observed: First, the increase in ciliate biomass resulted in higher $\mathrm{MCV}_{\mathrm{B}}$, in the second phase the increased $\mathrm{MCV}_{\mathrm{B}}$ was followed by a decline of the total predator biomass. These cycles were more pronounced on days $8,11,21$, and 44 . The $\mathrm{MCV}_{\mathrm{B}}$ reached a

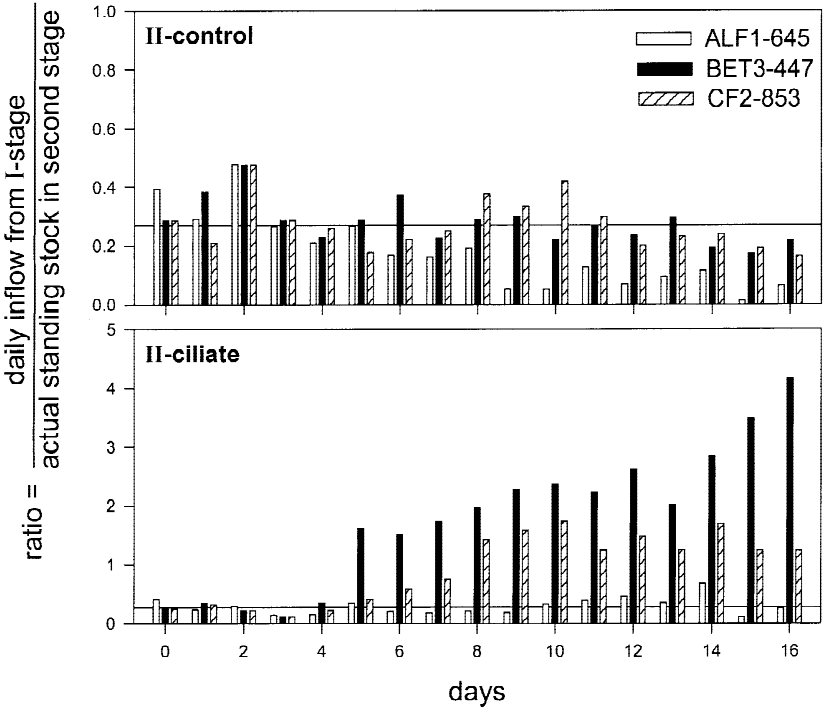

Fig. 4. The ratio of the daily input of bacteria (cells $\mathrm{ml}^{-1} \mathrm{~d}^{-1}$ ) targeted by specific oligonucleotide probes (ALF1-645, BET3-447, CF2-853) to the actual standing stock of these bacteria (cells $\mathrm{ml}^{-1}$ ) in the corresponding second stage. Solid lines stand for the expected ratio based on the dilution rate of $0.27\left(\mathrm{~d}^{-1}\right)$. Values $<0.27$ show that this taxonomic unit was more abundant than would be expected from the inflow-i.e., their abundance increased in the second stage. Values $>0.27$ mean that fewer bacteria were found than would be expected from the inflow-i.e., their abundance decreased in the second stage.

maximum at day 21, resulting in a strong decrease of the predator population. After day 37, ciliate biomass recovered slowly (Fig. 5).

\section{Size Selective Feeding of Cyclidium glaucoma}

Bacterial size class distributions on five selected days are presented in Fig. 6. Volumes of 0.25 to $>0.85 \mu \mathrm{m}$ sized spheres (in $0.05 \mu \mathrm{m}$ steps) were used as size classes for frequency distributions of bacterial cell volumes (Fig. 6). The size distribution of bacteria in I-stage shifted to larger cells during the experiment. Size distributions in II-control were on most days very similar to the patterns observed in I-stage. The BC in the stage with C. glaucoma showed very different size distributions. The frequencies of cells with volumes equivalent to spheres with $0.4-0.6 \mu \mathrm{m}$ diameter declined, whereas the proportion of larger cells increased during the experiment.

\section{Discussion}

Within 1 week, feeding by C. glaucoma strongly affected the bacterial community structure in respect to cell numbers 


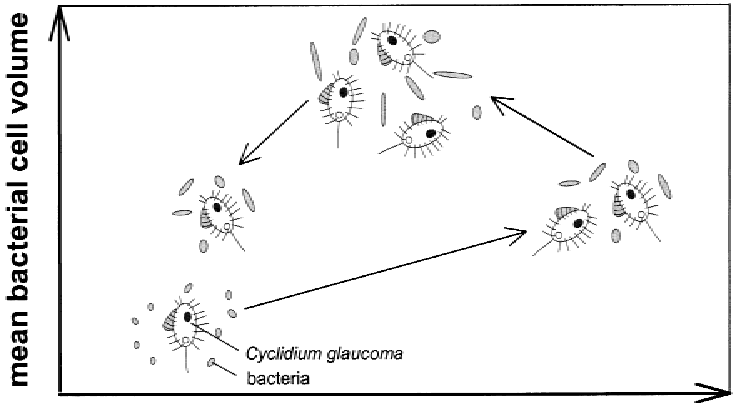

total ciliate biomass

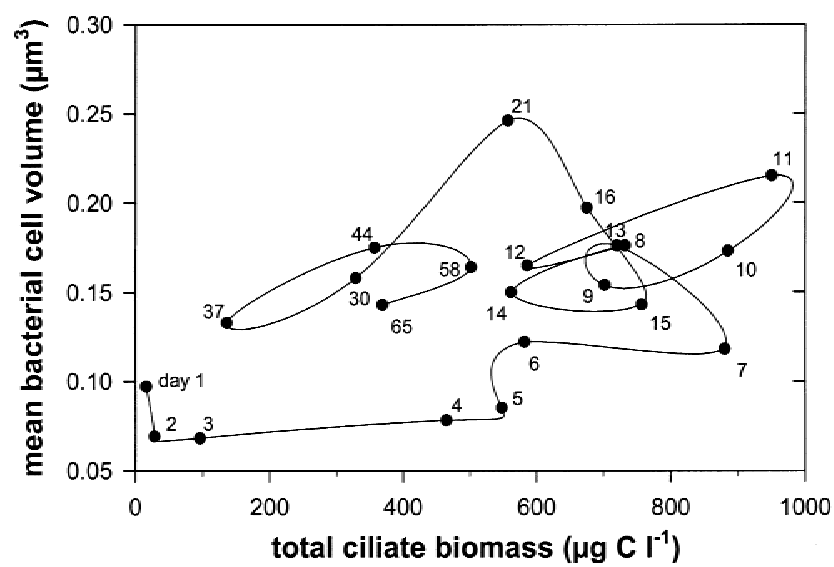

Fig. 5. Relationship between mean bacterial cell volume and total ciliate biomass (Cyclidium glaucoma). Upper panel: Schematic presentation of the predator-prey cycle. Lower panel: Note different sampling intervals (daily up to day 16, weekly sampling afterwards).

and size distribution. Thereafter, the protozoan biomass was always higher than the bacterial one. This was surprising as the bacterial inflow from I-stage should have served as a new food source for ciliates, but obviously could not maintain such high total grazing rates (Tab. 1). In fact, the daily inflow from I-stage was only equivalent to the remaining bacterial abundance determined in II-ciliate. We found that bacterial production in II-ciliate strongly increased to compensate for grazing induced cell losses. It is obvious that the daily bacterial production was so high that the community could reach the same abundances as found in II-control. This production, however, was completely removed by C. glaucoma. In a comparable experiment with C. glaucoma in 1998, we also observed that bacterial activity, measured by $\left[{ }^{14} \mathrm{C}\right]$ leucine and $\left[{ }^{3} \mathrm{H}\right]$ thymidine uptake, strongly increased after the inoculation of the bacterivorous protist (Fig. 5 in [23]).

As bacterial numbers remained stable at ca. $30-40 \%$ of the initial value, there must have been grazing defense mechanisms to survive the strong grazing pressure. Apart from the increase in growth rate to compensate for cell losses, we observed an increase in cell size. Cell volumes larger than $0.15 \mu \mathrm{m}^{3}$ seemed to lie outside the optimal food size range of the ciliate (Figs. 5 and 6). According to cell size distributions determined via image analysis the optimal food size would be particles between 0.3 and $0.6 \mu \mathrm{m}$ (Fig. 6). Several authors already determined uptake rates of differently sized prey particles (e.g., latex beads or FLB). We combined literature data $[5,30,35]$ on the genus Cyclidium with our own data on C. glaucoma to get a comprehensive picture of the optimal food size range for this scuticociliate (Fig. 7). Especially for natural particle concentrations between $10^{5}$ and $10^{7} \mathrm{ml}^{-1}$, only larger prey $>0.4 \mu \mathrm{m}$ diameter was tested. The highest uptake rates (particles ciliate ${ }^{-1} \mathrm{~min}^{-1}$ ) were found for $0.5-0.6 \mu \mathrm{m}$ particles at prey concentrations of $10^{5}$ to $10^{8} \mathrm{ml}^{-1}$. Fenchel [5] expressed the feeding efficiency as ingested volume per offered prey volume, and we completed this graph with other literature and our own data [30, 35]. Also in terms of ingested prey volume, C. glaucoma showed the highest feeding efficiency for $0.5-0.6 \mu \mathrm{m}$ particles (Fig. $7 \mathrm{~b})$. In summary, a wide prey size range has been tested but at very different concentrations. Therefore our synopsis is still based on an incomplete and heterogeneous data set. For example, Šimek et al. [35] used fluorescently labeled cells of a single bacterial strain (Alcaligenes xylosoxidans ssp. denitrificans) and observed significantly higher uptake rates for larger bacteria of $0.3-0.6 \mu \mathrm{m}^{3}$. These offered FLB were variable in length $(1-1.5 \mu \mathrm{m})$ but relatively constant in width (circa $0.6 \mu \mathrm{m}$ ). In comparison with other published and our own data (Fig. 7), we would expect very low uptake rates for such large cell volumes. This contradiction is probably explained by a misinterpretation of data derived from using spherical latex beads as food surrogates. For example, a spherical latex bead with a diameter of $0.6 \mu \mathrm{m}$ corresponds to a volume of $0.113 \mu \mathrm{m}^{3}$. A filter feeding ciliate will most probably select for the diameter of a spherical prey or for the width of a rod-shaped particle, but not for the prey volume. In the case of Cyclidium spp., it seems that particles of 0.5$0.6 \mu \mathrm{m}$ width are efficiently filtered even if they are some micrometers in length and their cell volumes are larger than $0.113 \mu \mathrm{m}^{3}$ [35]. In our experiments bacterial width was more strongly affected by grazing than length, indicating that becoming wider rather than longer may yield protection (Fig. 3, Table 1). In addition, we observed that uptake rates of FLB with a mean size of $0.94 \times 0.58 \mu \mathrm{m}$ (volume $=0.230$ $\mu \mathrm{m}^{3}$ ) were very similar to ingestion rates of $0.6 \mu \mathrm{m}$ spherical beads (volume $=0.113 \mu \mathrm{m}^{3}$, Fig. 7).

Data of the present and an earlier experiment [23] were 


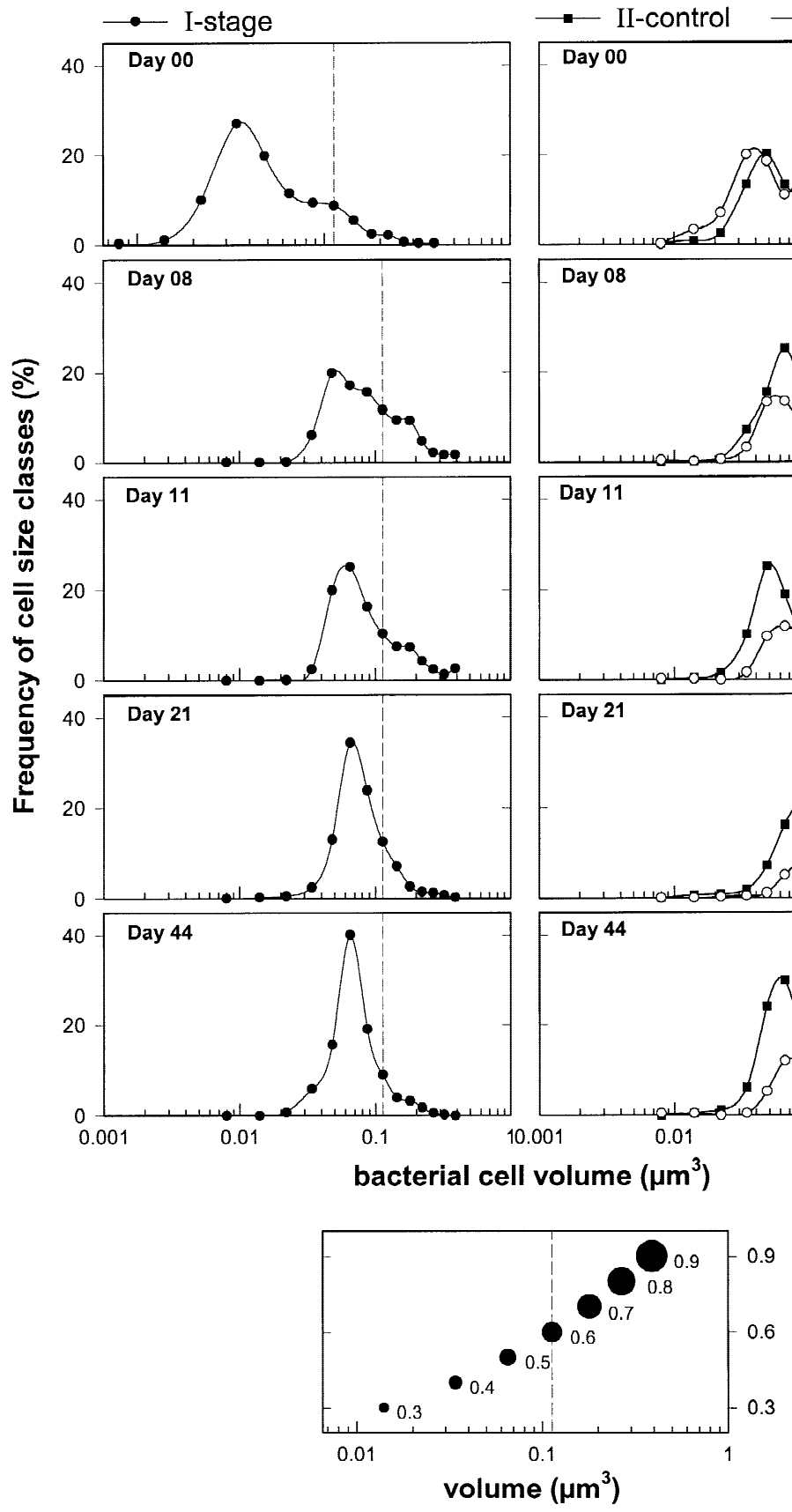

pooled $(n=37)$ to investigate the functional response of $C$. glaucoma feeding on FLB as prey-surrogates. As suggested by Fenchel [4], we plotted the reciprocal data on uptake and prey concentration (Fig. 8a) to calculate the maximal uptake $\left(\mathrm{U}_{\text {max }}\right)$ and clearance rate $\left(\mathrm{F}_{\max }\right)$. The reciprocal $y$-intercept of the regression line $\left(R^{2}=0.79\right)$ stands for $U_{\max }(1,016$ particles ciliate $\left.{ }^{-1} \mathrm{hr}^{-1}\right)$, the reciprocal value of the slope for $F_{\max }\left(119 \mathrm{nl}\right.$ ciliate $\left.^{-1} \mathrm{hr}^{-1}\right)$. A half saturation constant of $\mathrm{k}=$ $\mathrm{U}_{\max } / \mathrm{F}_{\max }=8.5 \times 10^{6}$ particles $\mathrm{ml}^{-1}$ was calculated. The measured maximal values of $946\left(\mathrm{U}_{\max }\right)$ and $149\left(\mathrm{~F}_{\max }\right)$ show reasonable agreement with the calculated data. The functional response of C. glaucoma follows the MichaelisMenten kinetic as shown in Fig. 8b. Therefore, we assume that the use of rod-shaped FLBs as prey surrogates allows a good description of the functional response of ciliates feeding on natural bacteria. In addition, a good characterization of optimal prey sizes and especially of truly ingested prey volume will be possible.

Despite the different observations on the optimal food size range of Cyclidium spp., we found a close relationship between mean prey size and population size of the predator (Fig. 5). This predator-prey cycle showed that an increase in 

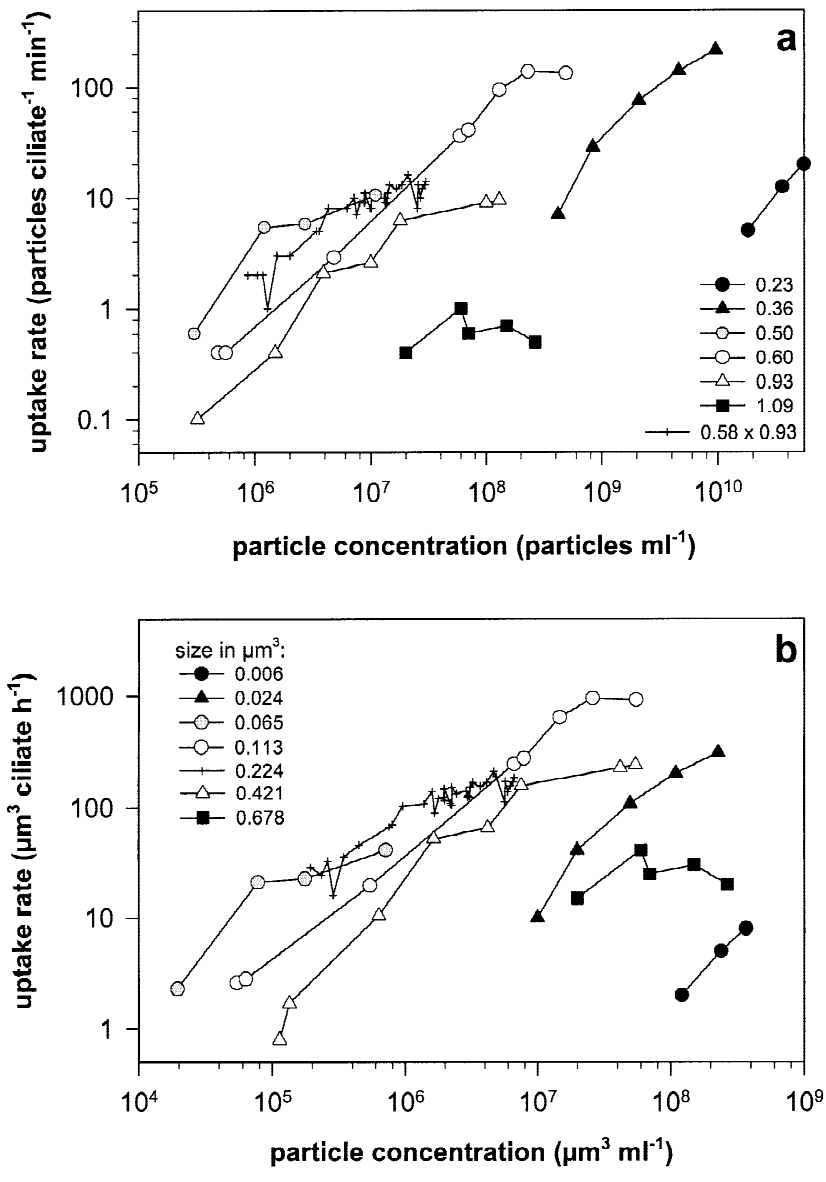

Fig. 7. Summary of literature and own data on size selective feeding of Cyclidium spp. (a) Prey concentration dependent uptake rates of spherical latex beads sized between 0.23 and $1.09 \mu \mathrm{m}$ are presented. Ingestion rates of FLB with a mean size of $0.94 \times 0.58$ $\mu \mathrm{m}$ (own data) and $0.5 \mu \mathrm{m}$ [35] are included. (b) Data on prey volume dependent uptake rates. Black symbols: latex beads, Fenchel [4]; white symbols: latex beads, Sanders [30]; gray symbols: FLB, Šimek et al. [35]; line with crosses: FLB, this study.

total predator biomass was accompanied by an increase in bacterial cell volume, which was followed by a strong decline of the ciliate population. Changes in bacterial cell volumes were mainly due to increasing cell widths, whereas cell lengths remained constant (Fig. 3). It seemed that the response of bacteria to grazing pressure yielded a feedback, resulting in an impairment of the predator. However, this relationship was highly variable as we observed at similar bacterial cell volumes very different protistan biomasses (e.g., days 8 and 44 in Fig. 5). We do not know if this is linked to the observed taxonomic shift within the $\mathrm{BC}$, perhaps toward less digestible strains. To our knowledge, it is the first time that, such a correlation between bacterial prey and a protistan predator has been described. Tanaka et al.
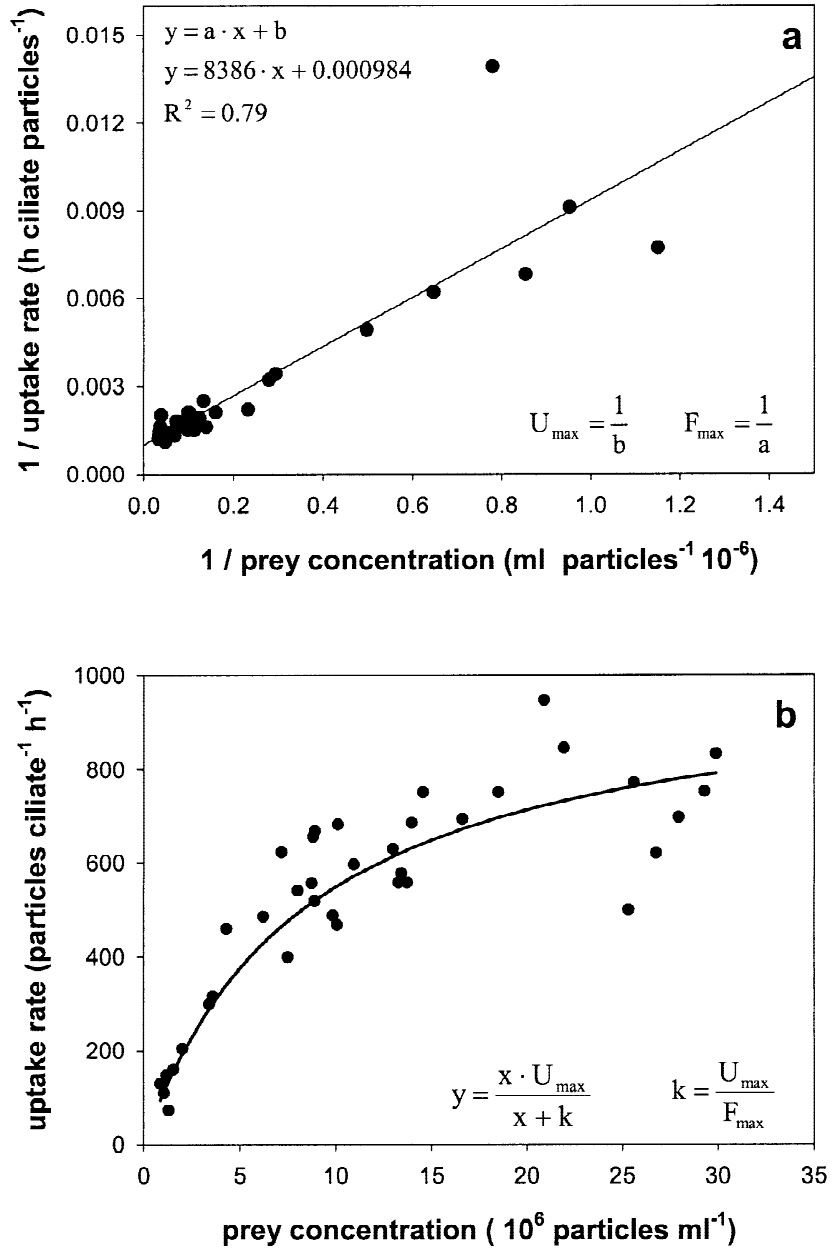

Fig. 8. Functional response of Cyclidium glaucoma feeding on FLB with a mean size of $0.58 \times 0.94 \mu \mathrm{m}$. (a) By plotting the reciprocal data on prey concentration and uptake rate, the maximal clearance $\left(\mathrm{F}_{\max }\right)$ and uptake rate $\left(\mathrm{U}_{\max }\right)$ can be determined. (b) After calculation of the half saturation constant $(\mathrm{k})$ the functional response can be presented following the Michaelis-Menten kinetic (see formula in the figure).

[39] found that the seasonal relationship between bacterial and HNF abundance can be presented in terms of cyclic oscillations. Although there is no further analogy between that study and our data, we can deduce at least how fast changes in microbial predator-prey systems may occur.

The extensive studies of Fenchel $[4,5]$ are certainly the basis for studying size selective feeding of ciliate species. However, we suggest for new investigations of optimal food size ranges, especially for filter feeding ciliates, using fluorescently labeled latex beads of a wide size range as well as fluorescently labeled bacteria of defined length and width. This study and especially the comparison with published data showed that prey geometry should not be disregarded in future investigations on optimal food size ranges. 


\section{Acknowledgments}

Thanks to R. Sommaruga and S. Klammer for their critical and helpful comments on the manuscript and to R. Folie and R. Psenner for the help during the experiments. We also thank H. Müller, M. Hahn, and M. Macek for providing protozoan cultures. T.P. was financed by a grant from the project "Effects of different protozan species on the diversity, morphology and activity of bacterial communities" (OENB 6513) sponsored by the Austrian National Bank. The study was also supported by AKTION Österreich-Tschechische Republik (Wissenschafts- und Erziehungskooperation), Projects No. 23p5 and No. 2000/22 to K.Š. and R. Psenner.

\section{References}

1. Begon M, Harper JL, Townsend CR (1990) Ecology. Individuals, Populations and Communities. Blackwell Scientific Publications, Boston

2. Bird DF, Kalff J (1993) Protozoan grazing and the size-activity structure of limnetic bacterial communities. Can J Fish Aquat Sci 50:370-380

3. delGiorgio PA, Gasol JM, Vaqué D, Mura P, Agusti S, Duarte CM (1996) Bacterioplankton community structure: protists control net production and the proportion of active bacteria in a coastal marine community. Limnol Oceanogr 41:1169_ 1179

4. Fenchel T (1980) Suspension feeding in ciliated protozoa: Functional response and particle size selection. Microb Ecol 6:1-11

5. Fenchel $\mathrm{T}$ (1980) Suspension feeding in ciliated protozoa: Feeding rates and their ecological significance. Microb Ecol 6:13-25

6. Foissner W, Berger H, Kohmann F (1994) Taxonomische und ökologische Revision der Ciliaten des Saprobiensystems. Band III: Hymenostomata, Prostomatida, Nassulida. Reports Issue 1/94, Bayerisches Landesamt für Wasserwirtschaft, München

7. Foissner W, Berger H, Schaumburg J (1999) Identification and ecology of limnetic plankton ciliates. Reports Issue 3/99, Bayerisches Landesamt für Wasserwirtschaft, München

8. Güde H (1979) Grazing by protozoa as selection factor for activated sludge bacteria. Microb Ecol 5:225-237

9. Güde H (1985) Influence of phagotrophic processes on the regeneration of nutrients in two-stage continuous culture systems. Microb Ecol 11:193-204

10. Guillard RRL, Lorenzen CJ (1972) Yellow-green algae with chlorophyllide $c$. J Phycol 8:10-14

11. Hahn MW, Höfle MG (1998) Grazing pressure by a bacterivorous flagellate reverses the relative abundance of Comamonas acidovorans PX54 and Vibrio strain CB5 in chemostat cocultures. Appl Environ Microbiol 64:1910-1918

12. Hahn MW, Höfle MG (1999) Flagellate predation on a bac- terial model community: interplay of size-selective grazing, specific bacterial cell size, and bacterial community composition. Appl Environ Microbiol 65:4863-4872

13. Hahn MW, Moore ERB, Höfle MG (1999) Bacterial filament formation, a defense mechanism against flagellate grazing, is growth rate controlled in bacteria of different phyla. Appl Environ Microbiol 65:25-35

14. Hahn MW, Moore ERB, Höfle MG (2000) Role of microcolony formation in the protistan grazing defense of the aquatic bacterium Pseudomonas sp. MWH1. Microb Ecol 39:175-185

15. Jürgens K, Güde H (1994) The potential importance of grazing-resistant bacteria in planktonic systems. Mar Ecol Prog Ser 112:169-188

16. Massana R, Gasol JM, Bjørnsen PK, Blackburn N, Hagström A, Hietanen S, Hygum BH, Kuparinen J, Pedrós-Alió C (1997) Measurement of bacterial size via image analysis of epifluorescence preparations: description of an inexpensive system and solutions to some of the most common problems. Scientia Marina 61:397-407

17. Monger BC, Landry MR, Brown SL (1999) Feeding selection of heterotrophic marine nanoflagellates based on the surface hydrophobicity of their picoplankton prey. Limnol Oceanogr 44:1917-1927

18. Norland S (1993) The relationship between biomass and volume of bacteria. In: Kemp PF, Sherr BF, Sherr EB, Cole JJ (eds) Handbook of Methods in Aquatic Microbial Ecology. Lewis Publishers, Boca Raton, FL, pp 303-307

19. Pace ML, Bailiff MD (1987) Evaluation of a fluorescent microsphere technique for measuring grazing rates of phagotrophic microorganisms. Mar Ecol Prog Ser 40:185-193

20. Pernthaler J, Posch T, Šimek K, Vrba J, Amann R, Psenner R (1997) Contrasting bacterial strategies to coexist with a flagellate predator in an experimental microbial assemblage. Appl Environ Microbiol 63:596-601

21. Pernthaler J, Posch T, Šimek K, Vrba J, Pernthaler A, Glöckner FO, Nübel U, Psenner R, Amann R, Predator-specific enrichment of Actinobacteria from a cosmopolitan freshwater clade in mixed continuous culture. Appl Environ Microbiol 67:2145-2155

22. Posch T, Pernthaler J, Alfreider A, Psenner R (1997) Cell specific respiratory activity of aquatic bacteria studied with the tetrazolium reduction method, Cyto-Clear slides, and image analysis. Appl Environ Microbiol 63:867-873

23. Posch T, Šimek K, Vrba J, Pernthaler J, Nedoma J, Sattler B, Sonntag B, Psenner R (1999) Predator-induced changes of bacterial size-structure and productivity studied on an experimental microbial community. Aquat Microb Ecol 18:235-246

24. Psenner R, Sommaruga R (1992) Are rapid changes in bacterial biomass caused by shifts from top-down to bottom-up control? Limnol Oceanogr 37:1092-1100

25. Putt M, Stoecker DK (1989) An experimentally determined carbon:volume ratio for marine "oligotrichous" ciliates from estuarine and coastal waters. Limnol Oceanogr 34:1097-1103

26. Rothhaupt KO (1992) Stimulation of phosphorus-limited 
phytoplankton by bacterivorous flagellates in laboratory experiments. Limnol Oceanogr 37:750-759

27. Rothhaupt KO (1996) Utilization of substitutable carbon and phosphorus sources by the mixotrophic chrysophyte Ochromonas sp. Ecology 77:706-715

28. Rothhaupt KO (1996) Laboratory experiments with a mixotrophic chrysophyte and obligately phagotrophic and phototrophic competitors. Ecology 77:716-724

29. Rothhaupt KO (1997) Nutrient turnover by freshwater bacterivorous flagellates: differences between a heterotrophic and a mixotrophic chrysophyte. Aquat Microb Ecol 12:65-70

30. Sanders RW (1988) Feeding by Cyclidium sp. (Ciliophora, Scuticociliatida) on particles of different sizes and surface properties. Bull Mar Sci 43:446-457

31. Sherr BF, Sherr EB, Fallon RD (1987) Use of monodispersed, fluorescently labeled bacteria to estimate in situ protozoan bacterivory. Appl Environ Microbiol 53:958-965

32. Sherr BF, Sherr EB, McDaniel J (1992) Effect of protistan grazing on the frequency of dividing cells in bacterioplankton assemblages. Appl Environ Microbiol 58:2381-2385

33. Sherr EB, Sherr BF (1993) Preservation and storage of samples for enumeration of heterotrophic protists. In: Kemp PF, Sherr BF, Sherr EB, Cole JJ (eds) Handbook of Methods in Aquatic Microbial Ecology. Lewis Publishers, Boca Raton, FL, pp 207212

34. Shikano S, Luckinbill LS, Kurihara Y (1989) Changes of traits in a bacterial population associated with protozoal predation. Microb Ecol 20:75-84

35. Simek K, Vrba J, Hartman P (1994) Size-selective feeding by Cyclidium sp. on bacterioplankton and various sizes of cultured bacteria. FEMS Microbiol Ecol 14:157-168

36. Simek K, Vrba J, Pernthaler J, Posch T, Hartman P, Nedoma J, Psenner R (1997) Morphological and compositional shifts in an experimental bacterial community influenced by protists with contrasting feeding modes. Appl Environ Microbiol 63:587-595

37. Šimek K, Kojecká P, Nedoma J, Hartman P, Vrba J, Dolan JR (1999) Shifts in bacterial community composition associated with different microzooplankton size fractions in a eutrophic reservoir. Limnol Oceanogr 44:1634-1644

38. Snyder RA, Hoch MP (1996) Consequences of protiststimulated bacterial production for estimating protist growth efficiences. Hydrobiologia 344:113-123

39. Tanaka T, Fujita N, Taniguchi A (1997) Predator-prey eddy in heterotrophic nanoflagellate-bacteria relationships in a coastal marine environment: a new scheme for predator-prey associations. Aquat Microb Ecol 13:249-256

40. Turley CM, Newell RC, Robins DB (1986) Survival strategies of two small marine ciliates and their role in regulating bacterial community structure under experimental conditions. Mar Ecol Prog Ser 33:59-70

41. Verity PG (1991) Feeding in planktonic protozoans: Evidence for non-random acquisition of prey. J Protozool 38:69-76 